\title{
Article \\ Study of the Rotary Bending Fatigue Resistance of 30MnB5, 41CrS4 and 30MnVS6 Steels
}

\author{
Ana Isabel García-Diez ${ }^{1, *(\mathbb{D})}$, Juan José Galán-Díaz ${ }^{2}$ (D) Manuel Ángel Graña-López ${ }^{3}$ (D) \\ and Mar Toledano-Prados ${ }^{2, *}$
}

1 Department of Naval and Industrial Engineer, Escuela Politécnica de Ingeniería de Ferrol, University of A Coruña, Ferrol Industrial Campus, 15403 Ferrol, Spain

2 Department of Naval and Industrial Engineering, ETSI Caminos, Canales y Puertos, University of A Coruña, 15008 A Coruña, Spain; juan.jose.galan@udc.es

3 Department of Industrial Engineer, Escuela Politécnica de Ingeniería de Ferrol, University of A Coruña, 15403 Ferrol, Spain; manuel.grana@udc.es

* Correspondence: ana.gdiez@udc.es (A.I.G.-D.); mar.toledano@udc.es (M.T.-P.)

check for updates

Citation: García-Diez, A.I.; Galán-Díaz, J.J.; Graña-López, M.Á.; Toledano-Prados, M. Study of the Rotary Bending Fatigue Resistance of 30MnB5, 41CrS4 and 30MnVS6 Steels. Appl. Sci. 2022, 12, 2369. https:// doi.org/10.3390/app12052369

Academic Editor: Jacek Tomków

Received: 27 January 2022

Accepted: 21 February 2022

Published: 24 February 2022

Publisher's Note: MDPI stays neutral with regard to jurisdictional claims in published maps and institutional affiliations.

Copyright: (c) 2022 by the authors. Licensee MDPI, Basel, Switzerland. This article is an open access article distributed under the terms and conditions of the Creative Commons Attribution (CC BY) license (https:// creativecommons.org/licenses/by/ $4.0 /)$.

\begin{abstract}
In this study, a comparative analysis of the fatigue behavior of four types of steels, three of quenching and tempering (30MnB5 subjected to two different heat treatments and 41CrS4) and one microalloyed (30MnVS6), was carried out. The objective of the study is to determine if it is feasible to replace the quenching and tempering steel traditionally used in the manufacture of commercial vehicle axles (30MnB5) with alternative ones with the same composition but with modifications in their microstructure that improve their mechanical properties; a quenched and tempered chromium steel $(41 \mathrm{CrS} 4)$ and one that is microalloyed (30MnVS6). For this, rotary-bending fatigue tests have been carried out on the four types of steels with different stress levels. The fatigue resistance of quenched and tempered steels and microalloyed steel was evaluated using the fit of Basquin's experimental data. Where possible, the fatigue limit was determined using the maximum likelihood method. It was concluded that, in general, the fatigue resistance of chromium-alloyed steel is higher than that of the reference steel, while the rest have lower fatigue resistance. On the other hand, it was determined that the fatigue limit of microalloyed steel is higher than the reference one and that of the reference steel is higher than that of the other two steels.
\end{abstract}

Keywords: microalloyed steels; quenching and tempering steels; rotary bending fatigue; Basquin method; maximum likelihood method

\section{Introduction}

The automotive industry is undoubtedly one of the most important industries today. This industry has a vital influence on the internal economy of both European and Asian countries, constituting an important factor in increasing employability [1,2]. In this industry great importance is attached to the selection of the materials used, determining this point both the production, use and maintenance costs, as well as the durability of the product $[3,4]$. A proper selection of materials used in the manufacture of components such as shafts, pistons and pumps can significantly reduce failures in service. The aforementioned components need to have important reliability characteristics. For this reason, it is required that they be made with materials that possess adequate mechanical properties of strength, rigidity and hardness, and a sufficiently high resistance to fatigue to avoid component failure [5].

Low and medium carbon quench and tempered steels are frequently used in the automotive industry for the manufacture of these components due to their high yield strength and mechanical strength. These steels contain alloying elements such as $\mathrm{Mn}, \mathrm{Cr}$, Mo and B, among others, which increase the hardness of the steel when it undergoes a quenching and tempering treatment [6]. 
Boron steel is a generic term for a family of low-alloy tempered and annealed steels. The study of these steels began during the Second World War and experienced a remarkable boost in the 1950s. As a result of the war, it was critical to find quality elements and it became necessary to find elements that would constitute an alternative to the more expensive binders. After a long experimental phase, boron steels only began to take hold in the 1970s and 1980s, due to the appearance of advanced steel technologies. Today they occupy a prominent position in the market for tempered and annealed steels. Boron steel alloys allow them superior strength after hardening by heat treatment. Boron is generally added to medium-carbon alloy steels to improve performance and to achieve similar performance compared to high carbon, and other costly alloyed steels. It is preferred to use this route rather than increasing the carbon and manganese content or adding chromium and molybdenum as this could reduce ductility during the manufacturing process. Boron steels, although they have other alloying elements, have boron as one of the main constituents. They are hypoeutectoid steels, with a ferritic matrix and with pearlite in their constitution, with about $0.25 \%$ carbon by mass. The presence of boron in this type of steels is very important for hardenability. Boron increases the hardenability of hypoeutectoid steels by retarding the nucleation of proeutectoid ferrite in the austenitic grain limits, and to a lesser extent, the transformation of higher bainite, which is nucleated by ferrite, without appreciably affecting the growth rate of these compounds [7]. A small amount of boron has a powerful effect on hardenability, increasing the hardening of the steel $[8,9]$. The influence on hardenability varies substantially with the carbon content in the composite. Boron is an interstitial element and has a very low solubility in $\alpha$-solid solution $(<0.003 \%)[10,11]$.

Boron steels coalesce at very high temperatures, and these steels combine wear resistance with high resistance at medium and high temperatures [12]. There are other factors that influence the effectiveness of boron, such as: the influence of nitrogen content, the influence of deoxidizers and the negative effect of high austenitizing temperature on the effect of boron on hardenability [13].

One of these boron steels is 30MnB5 (1.5531) steel, which is frequently used in the automotive industry to manufacture the front axles of industrial vehicles [14,15]. It is a steel alloyed with chromium and molybdenum and acquires its final mechanical properties after being subjected to a quenching and tempering treatment. The starting microstructure of this steel is, fundamentally, pearlitic, with the presence of some particles of ferrite and cementite [14-16], obtaining a microstructure formed mainly by tempered martensite $[15,16]$ after heat treatment. One of the advantages of $30 \mathrm{MnB5}$ steels is that quenching and tempering makes the steel stronger and harder, thus increasing the durability of the final components that usually have a useful life that is double or triple that of items made from $65 \mathrm{G}$ grade steels [17].

$41 \mathrm{CrS4}$ (1.7039) steel is also a quenched and tempered steel, and the fundamental difference to the previous one is that it is a chromium steel (between 0.9 and $1.2 \%$ ) and does not contain boron. This type of steel is also used in the automotive industry [18]. It has mechanical properties that can be comparable to those of the referenced boron steel [19]. Both boron steel (30MnB5) and chromium steel (41CrS4) are steels that require heat treatment for quenching and tempering to provide the required characteristics, so they can be replaced by other materials that avoid this process, thus saving energy costs and manufacturing time associated with it [20], which constitutes a search of notable interest. In this regard, microalloyed steels are an excellent alternative since they can have equivalent mechanical characteristics without the need to undergo any additional heat treatment. These steels can be presented in different structural forms, which are obtained by varying the composition of the microalloys [21,22]. However, it is necessary to ensure that, in addition to the savings benefits achieved by avoiding heat treatment, the required mechanical properties are maintained and have adequate resistance to fatigue [23].

A proposal to replace the previously mentioned reference quench and tempered steel (30MnB5) in the manufacture of commercial vehicle axles is 30MnVS6 steel (1.7225). This 
steel is a vanadium microalloyed steel with a high sulfur content, and that can be hardened by precipitation. During heating in the manufacturing process, vanadium dissolves in austenite, subsequently precipitating in the form of fine $\mathrm{V}(\mathrm{C}, \mathrm{N})$ particles, which favor the appearance of proeutectoid and pearlitic ferrite [20,24]. The sulfur content improves the machinability properties of steel $[25,26]$.

The steel currently used in the manufacture of this type of element, vehicle axles, does not present a specific problem that makes its substitution mandatory. However, if it were possible to find a material that improves the response to fatigue of the reference, this would imply an increase in the useful life of the parts. In this way, a clear economic benefit would be obtained. The alternatives proposed for this purpose must ensure, at least, mechanical properties (strength) similar to commercial steel.

The main objective of this research is twofold. On the one hand, evaluating whether a minimal modification in the mechanical properties of the reference steel, 30MnB5, that represents an improvement also implies a benefit in fatigue behavior. On the other hand, to determine if the two steels proposed as alternatives (the second for quenching and tempering, 41CrS4, and the microalloyed steel, 30MnVS6) can adequately replace conventional steel in the manufacture of axles in heavy vehicles. For this, in addition to complying with the requirements regarding mechanical properties, the fatigue behavior of both steels will be evaluated to ensure that the behavior of the proposed alternative is, at least, similar to the reference one. For this purpose, rotary-bending fatigue tests will be carried out according to ISO 1143: 2021 Metallic materials_-Rotating bar bending fatigue testing [27] on the four types of steels, and the observed fracture mechanisms will be evaluated, analyzing the fracture surface with a Scanning Electron Microscope (SEM).

\section{Materials and Methods}

Four different types of steels have been used for this study. The first two are boronalloyed quenching and tempering steels, designated $30 \mathrm{MnB} 5$, complying with the requirements of the standard UNE-EN ISO 683-2: 2019 Heat-treatable steels, alloy steels and free-cutting steels-Part 2: Alloy steels for quenching and tempering [28]. This type of steel is normally oil quenched. In the present study, it will be evaluated whether a quenching in water, which entails a modification in the mechanical properties and the fatigue behavior, is beneficial compared to the reference material quenched in oil. Oil-quenched boron steel will be called 30MnB5 (B1) and water-quenched 30MnB5 (B2). Steel B1 was subjected to a quenching treatment with an austenitization temperature of $800^{\circ} \mathrm{C}$ and subsequent cooling in oil for a period of $8 \mathrm{~min}$. Steel B2 was treated in the same way, but by modifying the cooling in oil by water and keeping the rest of the parameters. In both cases, after the hardening treatment, tempering was carried out. For this, a treatment temperature of $550{ }^{\circ} \mathrm{C}$ was used and the cooling was in the air. With this sequence, both present tempered martensite in their microstructure [14-16,29].

As an alternative to these two options, the use of another steel for quenching and tempering is proposed, $41 \mathrm{CrS4}$ (according to the same standard [28]) and a microalloyed steel, 30MnVS6, which meets the requirements established in the standard UNE-EN 10,267:1998 Ferritic-pearlitic steels for precipitation hardening from hot working temperatures $[20,24,30-32]$. The first (41CrS4) was subjected to a quenching and tempering treatment to obtain a tempered Martesite structure with the following parameters: austenization temperature of $850^{\circ} \mathrm{C}$ and cooling in water for $10 \mathrm{~min}$; tempering temperature of $540{ }^{\circ} \mathrm{C}$ and air cooling. Microalloyed steel is a pearlitic-ferritic steel that hardens by precipitation during the hot-forming process. It was tested without heat treatment since an alternative is sought that, avoiding this process, is competitive [33].

Table 1 shows the compositions, in percent by weight, indicated in the respective standards for the steels used in the study, and Table 2 indicates the required mechanical properties. For quenched and tempered steels, minimum values are established for the yield strength $\left(R_{\mathrm{e}}\right)$, elongation $(\varepsilon)$, stricture $(Z)$ and Charpy impact resistance measured with a V-notch (Charpy V-Notch, CVN), and a range of values for the tensile strength 
$\left(R_{m}\right)$. The same benchmarks are set for microalloyed steel, but there is no requirement for toughness.

Table 1. Composition of the steels used according to the corresponding standards.

\begin{tabular}{clccccccccccc}
\hline Steel & \% wt & C & Si & Mn & $\mathbf{P}$ & $\mathbf{S}$ & $\mathbf{C r}$ & $\mathbf{M o}$ & $\mathbf{C u}$ & $\mathbf{B}$ & $\mathbf{N}$ & $\mathbf{V}$ \\
\hline \multirow{2}{*}{ 30MnB5 } & $\min$ & 0.27 & - & 1.15 & - & - & - & - & - & 0.0008 & - & - \\
& $\max$ & 0.33 & 0.40 & 1.45 & 0.025 & 0.035 & - & - & 0.40 & 0.0050 & - & - \\
\hline \multirow{2}{*}{4 1CrS4 } & $\min$ & 0.38 & 0.10 & 0.60 & - & 0.02 & 0.90 & - & - & - & - & - \\
& $\max$ & 0.45 & 0.40 & 0.90 & 0.025 & 0.04 & 1.20 & - & - & - & - & - \\
\hline \multirow{2}{*}{30 MnVS6 } & $\min$ & 0.26 & 0.15 & 1.20 & 0.025 & 0.02 & - & - & - & - & 0.01 & 0.08 \\
& $\max$ & 0.33 & 0.80 & 1.60 & 0.05 & 0.06 & 0.30 & 0.08 & - & - & 0.02 & 0.20 \\
\hline
\end{tabular}

Table 2. Mechanical properties required by the standards for each steel.

\begin{tabular}{ccccccc}
\hline Steel & & $\mathbf{R}_{\mathbf{e}}(\mathbf{M P a})$ & $\mathbf{R}_{\mathbf{m}} \mathbf{( M P a )}$ & $\mathcal{\varepsilon}(\mathbf{\%})$ & $\mathbf{Z ~ ( \% )}$ & $\mathbf{C V N}(\mathbf{J})$ \\
\hline \multirow{2}{*}{30 MnB5 } & $\min$ & 650 & 800 & 13 & 50 & 60 \\
& $\max$ & - & 950 & - & - & - \\
\hline \multirow{2}{*}{$41 \mathrm{CrS4}$} & $\min$ & 560 & 800 & 14 & 40 & 55 \\
& $\max$ & - & 950 & - & - & - \\
\hline \multirow{2}{*}{30 MnVS6 } & $\min$ & 450 & 700 & 14 & 30 & - \\
& $\max$ & - & 900 & - & - & - \\
\hline
\end{tabular}

Tables 3 and 4 show the chemical composition and the mechanical properties determined for the steels used in the present research.

Table 3. Chemical composition of the four evaluated steels.

\begin{tabular}{cccccccccccc}
\hline Steel & Key & C & Si & Mn & P & S & Cr & Mo & B & N & V \\
\hline 30MnB5 & B1/B2 & 0.325 & 0.275 & 1.5 & 0.02 & 0.0275 & - & - & 0.0025 & - & - \\
\hline 41CrS4 & EC & 0.395 & 0.40 & 0.80 & 0.035 & 0.035 & 1.0 & - & - & - & - \\
\hline 30MnVS6 & MV & 0.36 & 0.62 & 1.4 & 0.022 & 0.057 & 0.19 & 0.03 & - & 0.13 & 0.09 \\
\hline
\end{tabular}

Table 4. Mechanical properties of the four types of steel evaluated.

\begin{tabular}{ccccccc}
\hline Steel & Key & $\mathbf{R}_{\mathbf{e}} \mathbf{( M P a )}$ & $\mathbf{R}_{\mathbf{m}} \mathbf{( M P a )}$ & $\varepsilon \mathbf{( \% )}$ & $\mathbf{Z ~ ( \% )}$ & $\mathbf{C V N}(\mathbf{J})$ \\
\hline \multirow{2}{*}{$30 \mathrm{MnB5}$} & B1 & 851 & 944 & 14.18 & 59.27 & 98 \\
& B2 & 915 & 1006 & 14.52 & 55.69 & - \\
\hline \multirow{2}{*}{ 31CrS4 } & EC & 982 & 1062 & 12.69 & 56.52 & - \\
\hline 30MVS6 & MV & 617 & 889 & 12 & 40.9 & 50 \\
\hline
\end{tabular}

As can be seen in the values shown in Table 4, the tensile strength and the yield strength of boron steel tempered in water (B2) are higher than the values shown for traditional steel tempered in oil (B1). The steel hardened and annealed with chromium (EC) presents higher values than the previous two, while the microalloyed steel (MV) reaches lower values. It is also observed that the $R_{e} / R_{m}$ ratio for B1, B2 and EC steels is similar: 0.90, 0.91 and 0.93 respectively. For MV steel this ratio is significantly reduced to 0.69 .

Aliakbari et al. [34] state that the majority of combustion engine vehicle axle failures are due to fatigue failures related to bending stresses. Therefore, the evaluation of the fatigue resistance of alternative steels is essential to establish whether the reference steel-30SnB5 (B1) — can be substituted for them. 
In order to evaluate the fatigue behavior of the two steels considered in the study, the rotary-bending fatigue test was used, following the corresponding standard [27]. Figure 1 shows the device used for the fatigue tests and a detailed image of the clamping of the specimen.

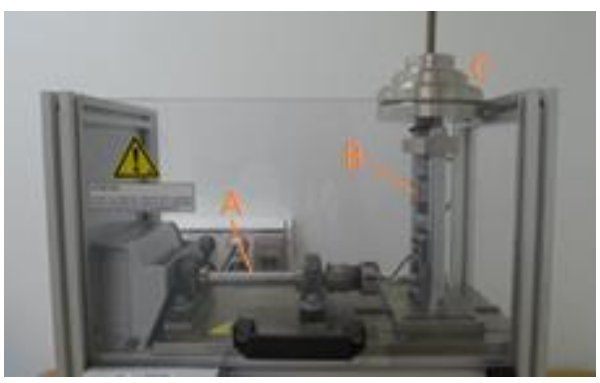

(a)

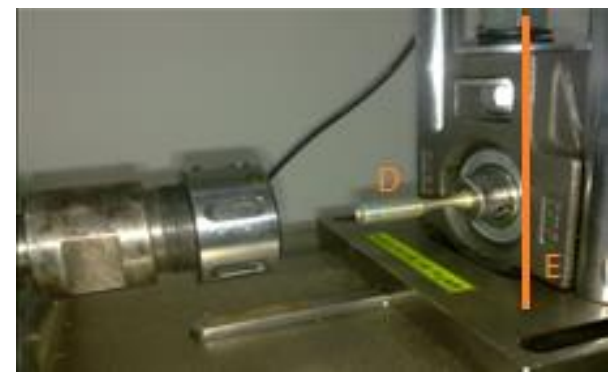

(b)

Figure 1. Device used for the test (a) A more detailed view of the same device (b). In the figure, $A$ is axis of rotation linked to the motor at the far left of the figure, B the force transducer, $C$ the masses, D the sample and $\mathrm{E}$ the load axis at the end of the specimen.

In this type of test, the stress is applied to the specimen in the form of a bending moment generated by applying a load to one of the ends of the specimen. In this way, the specimen, at a given moment, has an induced tensile stress on the upper surface, while the lower surface is subjected to compression (Figure 2). This situation is reversed when the specimen is rotated, establishing a complete cycle in each rotation $[35,36]$. Under these alternating stress conditions, the load ratio is $\mathrm{R}=-1$.

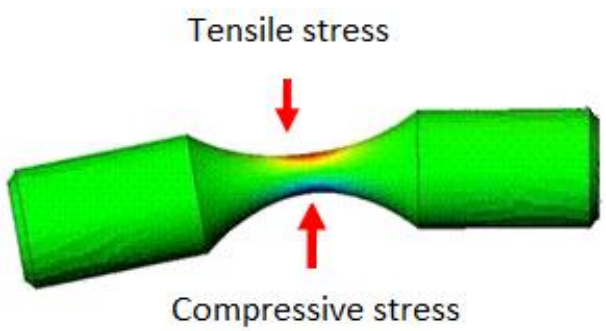

Figure 2. Stresses on the specimen at a given instant of the test (tension in the upper part and compression in the lower part).

The geometry of the tested specimens corresponds to the type 3 set forth in the standard (Hourglass specimen-Single-point loading), The dimensions of the specimens are shown in Figure 3a. The assembly scheme of the specimen in the test equipment is shown in Figure $3 b$.

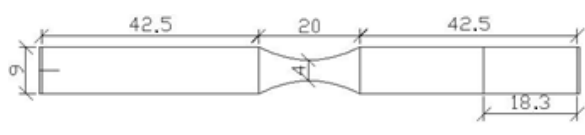

(a)

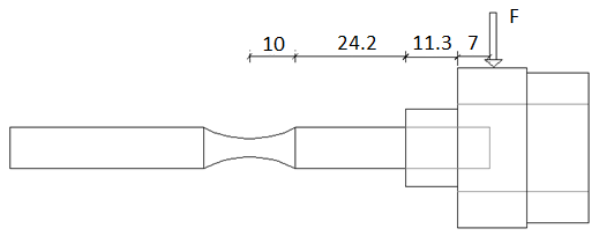

(b)

Figure 3. Shape and dimensions of the tested specimens (a) Assembly of the specimen in the test device (b).

As can be seen in the figure, the specimens have a cylindrical section of $4 \mathrm{~mm}(\mathrm{~d})$ in the test area and $9 \mathrm{~mm}$ (D) in the clamping area. The samples have been carefully machined, 
maintaining an average roughness, $\mathrm{Ra}$, less than $0.2 \mu \mathrm{m}$ as recommended in the standard and in other previously published studies [27,37]. Since the initiation of fatigue cracks is a process that takes place preferentially on the surface [38], if there was a poor or uneven preparation of the samples, the results obtained could present a very high dispersion and be inconclusive.

The determination of the applied stress in the specimen is carried out using the following equation:

$$
\mathrm{S}=\mathrm{K} \frac{\mathrm{Mc}}{\mathrm{I}}
$$

where $\mathrm{K}$ is the stress concentration factor, $\mathrm{M}$ the bending moment of the force applied to the specimen, $\mathrm{c}$ is the distance perpendicular to the neutral axis from where the maximum stress acts $\left(\sigma_{\mathrm{m}}\right)$ and I the moment of inertia of the cross section.

To calculate $\mathrm{K}$, it is taken into account that the relationship between $\mathrm{D} / \mathrm{d}$ and $\mathrm{r} / \mathrm{d}$ is 2.2 and 5, respectively (where $r$ is the radius of agreement, $20 \mathrm{~mm}$ ). The result obtained for $\mathrm{K}$ is a value close to 1 [39]. For the type of geometry used, the corresponding standard [27] establishes that the applied force is determined with the following expression:

$$
F=S \frac{\pi d^{3}}{32(L-x)}
$$

where $\mathrm{L}$ is the length from the clamping point of the specimen to the point of application of the load and $x$ is the distance between the clamping point and the midpoint of the sample. For the tested specimens, the distance $(\mathrm{L}-\mathrm{x})$ is $52.5 \mathrm{~mm}$.

In the rotary-bending fatigue tests carried out, different stress levels have been used. The values used have been chosen as percentages of the yield strength provided by the manufacturer for each type of steel and are shown in Table 5. In none of the cases has 100\% of the yield strength been reached to avoid fatigue tests being carried out in the plastic regime of the steels. In order to cover the widest possible range of stresses, values between $40 \%$ and $90 \%$ of $R_{e}$ have been proposed

Table 5. Values of maximum stress amplitudes, S (MPa), used in the rotary-bending tests for each evaluated steel.

\begin{tabular}{ccccc}
\hline Key & B1 & B2 & EC & MV \\
\hline MPa & 30MnB5 & 30MnB5 & 41CrS4 & 30MnVS6 \\
\hline $40 \% R_{e}$ & - & 366 & 393 & - \\
$50 \% R_{e}$ & 424 & - & 494 & 324 \\
$60 \% R_{e}$ & 511 & 559 & 586 & 388 \\
$70 \% R_{e}$ & 596 & 653 & 685 & 452 \\
$78 \% R_{e}$ & - & 717 & 838 & - \\
$85 \% R_{e}$ & 723 & 777 & - & 581 \\
$90 \% R_{e}$ & - & & & - \\
\hline
\end{tabular}

The Wöhler curves (S-N), where $\mathrm{N}$ is the numbers of cycles, for ferrous alloys show a limiting stress below which fatigue failure does not occur [40,41]. This value, known as the fatigue resistance limit, is the inversion point of the S-N curve and it is normally in the range of $10^{5}$ to $10^{7}$ cycles. Considering this range of values, the decision was made to end the fatigue test in $10^{6}$ cycles. From $10^{6}$ cycles, infinite life fatigue would be considered for the materials under study.

The results obtained in the rotary-bending fatigue tests have been refined using the Grubbs statistical analysis [42]. This statistical treatment made it possible to discard atypical or extreme results that presented discordance with the rest of the measurements.

The Wöhler curve was fitted using the Basquin method [43]. A characteristic of fatigue tests is that, despite their large dispersion, the fatigue resistance data (for a specific stress level) follow a logarithmic distribution (Gaussian distribution). Thus, it is possible to use 
the associated half-life curve and the standard deviation to define a calculation S-N curve for any probability of fatigue [44]. This methodology is the one that was used to carry out the comparative analysis of the fatigue results of the four types of steels.

For the determination of the fatigue limit, in the cases in which it was possible, the maximum likelihood method was used [45,46], with which, from a sample of data, it was sought to find the population with the highest probability having generated this sample. A detailed explanation of this statistical method, used for parameter estimation with great frequency, was published by Myung in 2003 [47].

Finally, an analysis of the fracture surfaces was carried out after the rotary bending fatigue tests in the two alternative types of steels evaluated by means of observation with scanning electron microscopy (SEM).

\section{Results and Discussion}

Firstly, the S-N curve was parameterized using the Basquin equation, allowing the prediction of fatigue resistance in the finite life range, which is between approximately one thousand and one million cycles. Fitting the S-N curves using the Basquin method is equivalent to expressing the fatigue strength as a straight line of slope $b$ in the S-N diagram represented in logarithmic scale:

$$
\begin{gathered}
\mathrm{S}=\mathrm{AN}^{\mathrm{b}} \\
\log \mathrm{S}=\mathrm{b} \times \log \mathrm{N}+\mathrm{C}, \text { donde } \mathrm{C}=\log \mathrm{A}
\end{gathered}
$$

where $\mathrm{A}$ and $\mathrm{b}$ are the characteristic fitting coefficients of the material and of the test conditions that are determined experimentally. A represents the stress required to produce the fracture with only one stress cycle, and b is the so-called Basquin exponent. The Basquin exponent characterizes the sensitivity to the change in the number of failure cycles when a certain stress level is applied.

For the 30MnB5-B1 steel (reference steel), four specimens were tested at the $60 \% \mathrm{R}_{\mathrm{e}}$ level (511 MPa), of which two did not break. At the $50 \% \mathrm{R}_{\mathrm{e}}$ level, two specimens were tested and none broke. For the 30MnB5-B2 steel (water quenched), four specimens were tested at the $40 \% \mathrm{R}_{\mathrm{e}}$ level and all broke. For 41CrS4-EC steel, the minimum load level tested was $40 \%$ of $\mathrm{R}_{\mathrm{e}}(393 \mathrm{MPa})$ and the four specimens broke. Finally, for the 30MnVS6-MV steel, six specimens were tested at the $50 \%$ level of $\mathrm{R}_{\mathrm{e}}(324 \mathrm{MPa})$, of which two did not break, so it was decided not to test at lower load level. Therefore, for B1 and MV steels, the minimum stress value tested was $50 \%$ of $R_{e}$, since for lower values the infinite life regime was entered. For high load values, only for MV steel adequate results were obtained when the stress level was $90 \%$ of $R_{e}$, so that for the rest of the samples the maximum tension tested was $85 \%$ of $\mathrm{R}_{\mathrm{e}}$.

\subsection{Fatigue Resistance}

In Figure 4 the experimental S-N curves of the tested steels and the fitted curve are shown, and in Table 6 the values obtained for the fitting coefficients of the Basquin equation and the regression coefficient, $\mathrm{R}^{2}$.

Table 6. Fitting coefficients, A and b, obtained with the Basquin method and regression coefficient of the fitting coefficients.

\begin{tabular}{ccccc}
\hline Steel & Key & A (MPa) & b & $\mathbf{R}^{\mathbf{2}}$ \\
\hline 30MnB5 & B1 & 2048 & -0.123 & 0.62 \\
30MnB5 & B2 & 3701 & -0.188 & 0.98 \\
41CrS4 & EC & 4407 & -0.198 & 0.95 \\
30MnVS6 & MV & 1755 & -0.126 & 0.42 \\
\hline
\end{tabular}




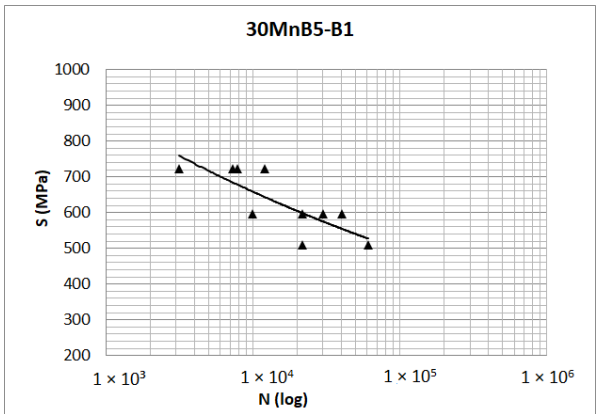

(a)

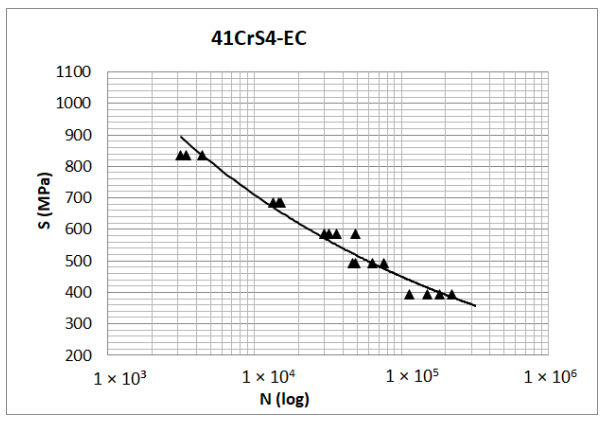

(c)

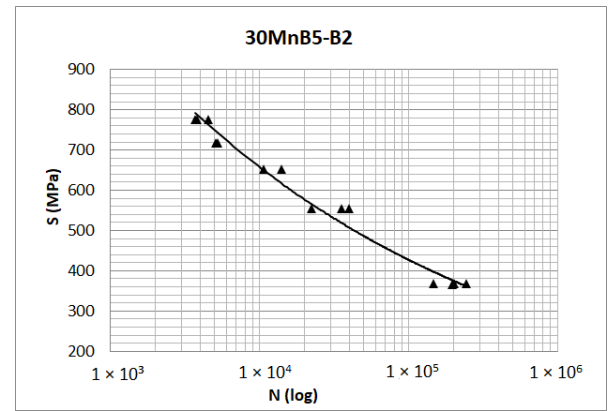

(b)

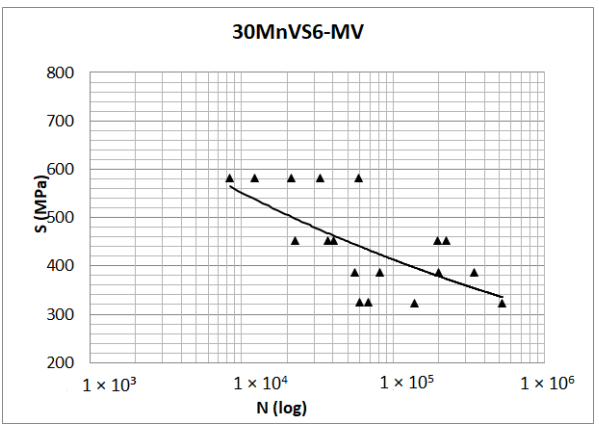

(d)

Figure 4. S-N curves obtained with the experimental data of the rotary-bending fatigue tests for the reference quenched and tempered steel (a) modified (b), alternative chromium quenched and tempered steel (c) and microalloyed steel (d).

In Figure 4a it can be observed that in the case of the 30MnB5 reference steel (B1), only the data of three stress levels are represented, since for the lowest level tested ( $50 \%$ of $R_{\mathrm{e}}$ ) none of the specimens broke, and at the next level, $60 \% \mathrm{R}_{\mathrm{e}}$, only two of them did. For B1 and MV steels a high dispersion is observed, in particular at the highest load levels; this was due to the fact that the specimens supplied by the manufacturer had a higher surface roughness than the other two materials. In all cases, a surface roughness, Ra, lower than the value of 0.2 microns established was ensured, so it is guaranteed that the four steels have an adequate surface finish to obtain results in valid fatigue tests.

As already indicated, despite the great dispersion in the data, the Wöhler curves can be analyzed by means of a statistical treatment that allows defining a calculation S-N curve for any probability of fatigue. In this way, this curve will be used as a reference to compare the fatigue response of the four types of steel studied. With the data from the fatigue tests in the finite life range, the arithmetic mean of the failure cycles was calculated, $\overline{\mathrm{N}}$, he standard deviation, $D$, and the standard error of the mean value of the number of cycles, $D_{\overline{\mathrm{N}}}$. Table 7 shows the values obtained for these parameters.

From the data in Table 7, the compared fatigue resistance was represented for the four steels evaluated (Figure 5).

From Figures 4 and 5 it can be observed that the fatigue resistance of the reference $30 \mathrm{MnB5}$ (B1) steel (blue line) is slightly higher than that observed for the same modified steel (B2), despite the fact that the yield strength and the tensile strength of the latter is greater. Microalloyed steel with vanadium (30MnVS6, orange line) has a resistance to fatigue very similar to that of reference steel for low load values. Since its elastic limit is significantly lower, its application with high loads is ruled out. Furthermore, with load values lower than $500 \mathrm{MPa}$, the fatigue behavior is clearly worse than that of the reference steel, which at that load level seems to have reached the fatigue limit. The quenched and tempered chrome steel (41CrS4-EC) has a higher fatigue resistance than the other steels in the range of stresses studied. However, in this stress range it was not possible to establish 
a fatigue limit, as was the case for both the reference steel and the microalloyed steel. To determine this limit, further tests will be necessary, which will be addressed in later studies.

Table 7. Statistical values obtained for the experimental fatigue data.

\begin{tabular}{|c|c|c|c|c|c|}
\hline Steel & Key & $S$ & $\overline{\mathbf{N}}$ & D & $\mathrm{D}_{\overline{\mathrm{N}}}$ \\
\hline \multirow{3}{*}{ 30MnB5 } & \multirow{3}{*}{ B1 } & 723 & 7570 & 3646 & 1823 \\
\hline & & 596 & 2558 & 12,927 & 6463 \\
\hline & & 511 & 41,272 & 27,451 & 19,411 \\
\hline \multirow{5}{*}{ 30MnB5 } & \multirow{5}{*}{ B2 } & 777 & 4018 & 461 & 266 \\
\hline & & 717 & 5133 & 110 & 78 \\
\hline & & 653 & 12,360 & 2359 & 1668 \\
\hline & & 555 & 3292 & 9081 & 5243 \\
\hline & & 368 & 197,278 & 33,871 & 16,935 \\
\hline \multirow{5}{*}{ 41CrS4 } & \multirow{5}{*}{$\mathrm{EC}$} & 836 & 3671 & 671 & 387 \\
\hline & & 685 & 14,446 & 911 & 526 \\
\hline & & 585 & 36,579 & 8269 & 4135 \\
\hline & & 493 & 58,825 & 13,922 & 6961 \\
\hline & & 393 & 166,047 & 45,099 & 22,550 \\
\hline \multirow{4}{*}{ 30MnVS6 } & \multirow{4}{*}{ MV } & 581 & 26,758 & 20,361 & 9106 \\
\hline & & 452 & 104,264 & 97,701 & 43,693 \\
\hline & & 388 & 169,139 & 130,124 & 65,062 \\
\hline & & 324 & 198,301 & 221,258 & 110,629 \\
\hline
\end{tabular}

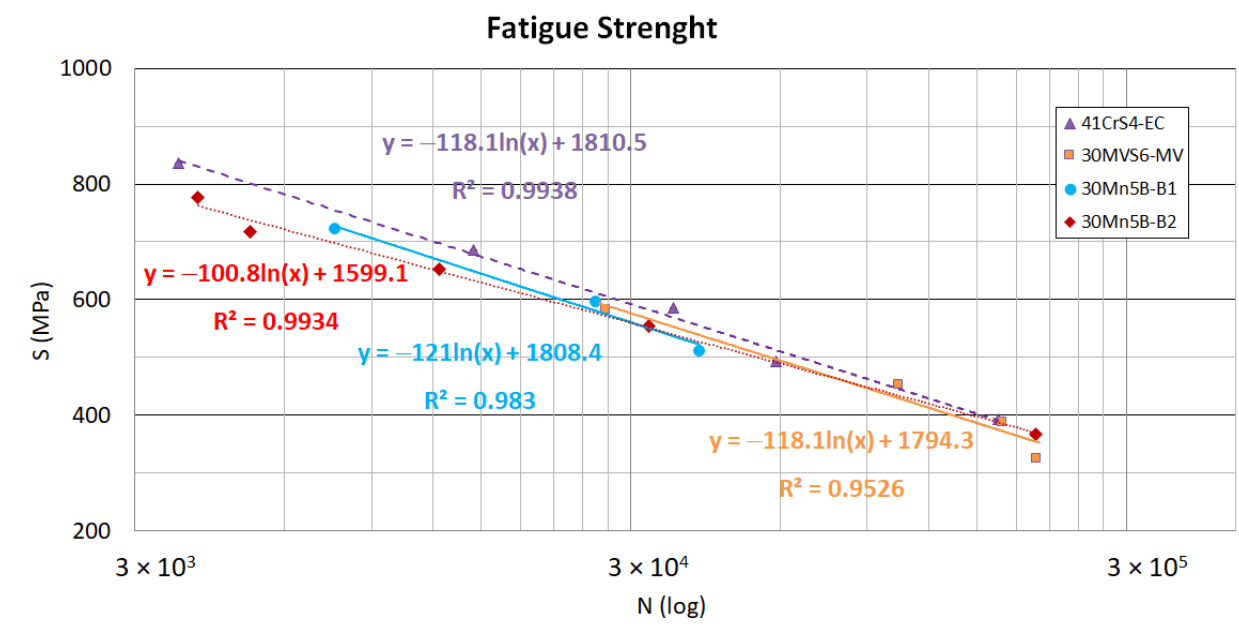

Figure 5. Fatigue resistance for each of the four types of steels evaluated.

\subsection{Fatigue Limit}

For B1 and MV steels the run-out data were used (Specimens surviving the $10^{6}$-cycle program) to evaluate the limit of resistance to fatigue. This limit represents the load threshold for fatigue stress states, below which it can be assumed that the useful life of the material is infinite. The statistical calculation procedure used was the maximum likelihood method, which is based on the hypothesis of normality in the fatigue limit distribution [48], and that the probability of observing what has been obtained experimentally will be:

$$
\mathrm{V}=\prod_{\mathrm{i}=1}^{\mathrm{n}}\left[1-\mathrm{P}\left(\mathrm{S}_{\mathrm{i}}, \overline{\mathrm{x}}, \sigma\right)\right]^{\mathrm{r}_{\mathrm{i}}}\left[1-\mathrm{P}\left(\mathrm{S}_{\mathrm{i}}, \overline{\mathrm{x}}, \sigma\right)\right]^{\mathrm{f}_{\mathrm{i}}}
$$


where $r_{i}$ is the number of runouts at the $i$-th load level $\left(S_{i}\right), f_{i}$ is the number of failures observed at that same stress level, $\mathrm{P}$ is the cumulative probability of failure, $\bar{x}$ is the mean value and $\sigma$ the standard deviation. The value of $\mathrm{P}$ is calculated according to Equation (5).

$$
P(S, \bar{x}, \sigma)=\int_{-\infty}^{S} \frac{1}{\sigma \sqrt{2 \pi}} \exp \left[-\frac{1}{2}\left(\frac{\bar{x}-x}{\sigma}\right)^{2}\right] d x
$$

To maximize the likelihood, the values of $\bar{x}$ and $\sigma$ that maximize the probability are calculated, for which Equation (4) is expressed as a natural logarithm.

$$
\ln \mathrm{V}=\sum_{\mathrm{i}=1}^{\mathrm{n}} \mathrm{r}_{\mathrm{i}} \ln \left(1-\mathrm{P}_{\mathrm{i}}\right)+\mathrm{f}_{\mathrm{i}} \ln \mathrm{P}_{\mathrm{i}}
$$

where $P_{i}$ es $P\left(S_{i}, \bar{x}, \sigma\right)$. Using the Matlab program, the partial derivatives with respect to $\bar{x}$ and $\sigma$ are calculated and set equal to zero, thus determining the values of the fatigue limit, $\overline{\mathrm{S}}_{1}$, and the corresponding standard deviation, D [49]. The results for the 30MnB5-B1 and 30MnVS6-MV steels are shown in Table 8.

Table 8. Fatigue limit values and standard deviation obtained for the 30MnB5-B1 and 30MnVS6-MV steels with the maximum likelihood method.

\begin{tabular}{cccc}
\hline Steel & Key & $\overline{\mathbf{S}_{\mathbf{l}}} \mathbf{( M P a )}$ & $\mathbf{D}$ (MPa) \\
\hline 30MnB5 & B1 & 326.16 & 7.34 \\
30MnVS6 & MV & 233.72 & 153.49 \\
\hline
\end{tabular}

According to these data, the fatigue limit that represents the maximum load threshold, which guarantees the infinite life of the material in fatigue, is $326 \mathrm{MPa}$ for quenched and tempered steel (B1) and $233 \mathrm{MPa}$ for microalloyed steel (MV). Comparing the results presented, the fatigue limit of microalloyed steels represents a decrease of $28 \%$ in the load capacity in fatigue with respect to quenched and tempered steels. In both cases these values represent approximately $38 \%$ of their respective yield strengths. On the other hand, the fatigue index, which represents the relationship between the limit of fatigue resistance and tensile strength, is $45 \%$ and $40 \%$ for B1 and MV steels, respectively. The resistance reduction is more significant, from this point of view, for B1 than for MV. These results could indicate a greater correlation between the yield strength (associated with plastic deformation and, therefore, dislocation displacement) than with tensile strength.

\subsection{Fractography}

In order to complement the analysis of the fatigue behavior, the study of the fracture surface was carried out by means of scanning electron microscopy (SEM). Representative samples of each steel were chosen. In the most interesting cases, photos were taken at higher magnifications to study the cracks or micro holes that could be associated with the fracture process, due to the inclusion of second-phase particles.

The images in Figure 6 correspond to the reference tempering and tempering steel specimen (30MnB5-B1) tested at a stress level of $70 \%$ of its yield strength, equivalent to the stress of $596 \mathrm{MPa}$. The fracture occurred at 29,987 cycles. Image (a) shows the global fracture surface. The area marked with a white circle indicates the separation between the fatigue failure zone and the final ductile fracture. Image (b) shows the density of holes found in the ductile fracture zone. 


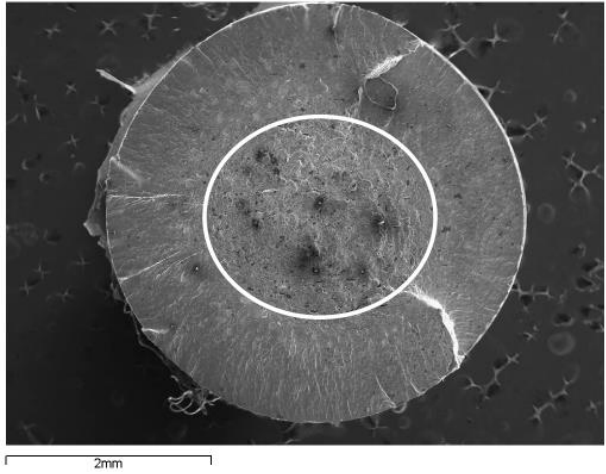

(a)

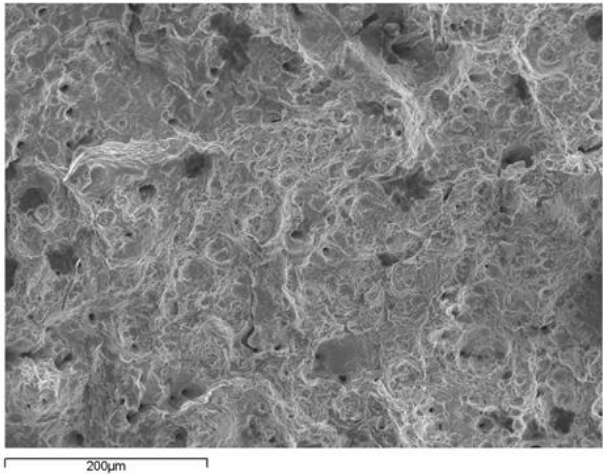

(b)

Figure 6. Fracture surface of the reference quenched and tempered steel (30MnB5-B1) subjected to the rotary bending fatigue test with a stress of $70 \% R_{e}$. (Complete fracture surface (a) and detail (b)).

Figure 7a shows the complete fracture surface observed for the 30MnB5 (B2) steel subjected to a stress of $559 \mathrm{MPa}\left(60 \% \mathrm{R}_{\mathrm{e}}\right)$. The fracture occurred at 35,259 cycles. The final fracture occurs in the marked area. Figure $7 \mathrm{~b}$ shows an enlargement of this fracture zone, where very little ductility is observed.

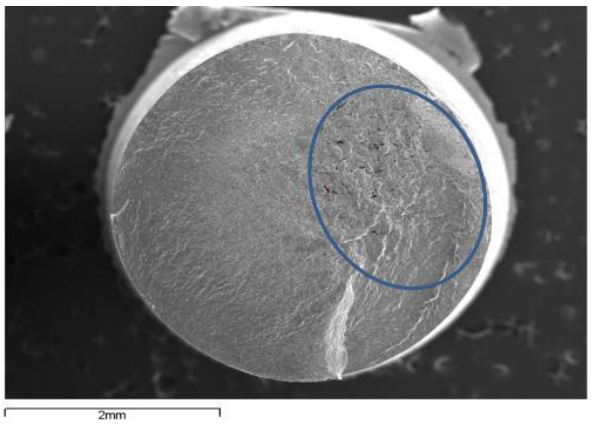

(a)

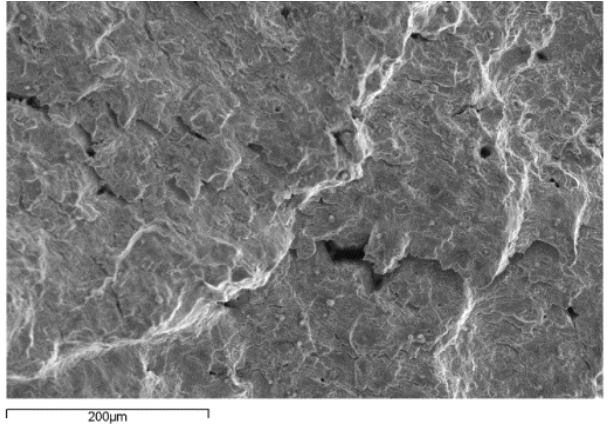

(b)

Figure 7. Fracture surface of modified quenched and tempered steel (30MnB5-B2) subjected to rotary bending fatigue test with a stress of $552 \mathrm{MPa}$. (Complete fracture surface (a) and detail (b)).

Figure 8 shows the SEM images obtained for the 30MnVS6 microalloyed steel tested with a stress of $581 \mathrm{MPa}$, which corresponds to $90 \%$ of its elastic limit. The fracture was reached at 32,754 cycles. Figure 8a shows the complete fracture of the specimen. On this image, the line that marks the difference between the fatigue fracture and the final ductile fracture was represented. Figure $8 \mathrm{~b}$ shows the ductile fracture zone in detail, where the high density of cracks associated with ductile fracture can be seen, with an average size between 30 and $75 \mu \mathrm{m}$. In its interior are some second phase particles, which are possibly the triggers of the crack.

Figure 9 shows the images of the failure surface obtained for the quenched and tempered steel alloyed with chromium (41CrS4-EC) when it is tested with a stress equivalent to $60 \%$ of its elastic limit (586 MPa). The number of cycles to failure was 36,062. Image (a) shows the general appearance of the fracture. The area where the final fracture occurs was marked. Image (b) shows this area with higher magnifications. A brittle fracture with tear can be observed, as well as micro voids generated by the cohesion of particles. 


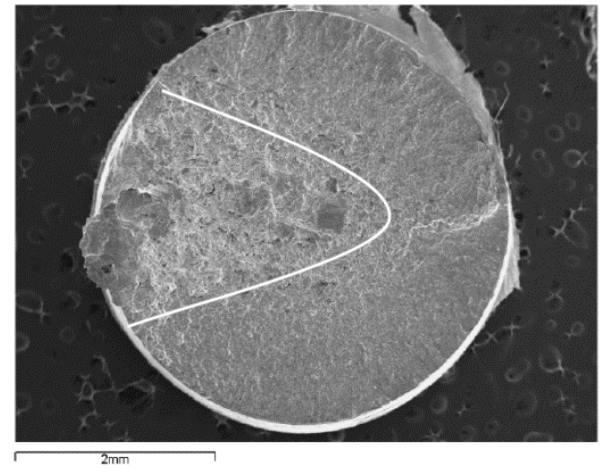

(a)

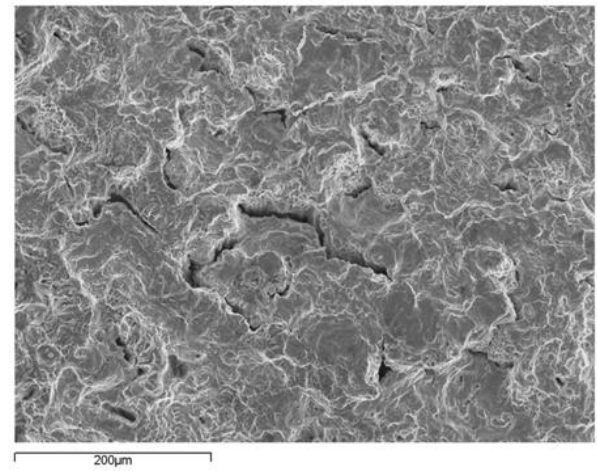

(b)

Figure 8. Fracture surface of microalloyed steel subjected to rotary bending fatigue test with a stress of $584 \mathrm{MPa}$. (Complete fracture surface (a) and detail (b)).

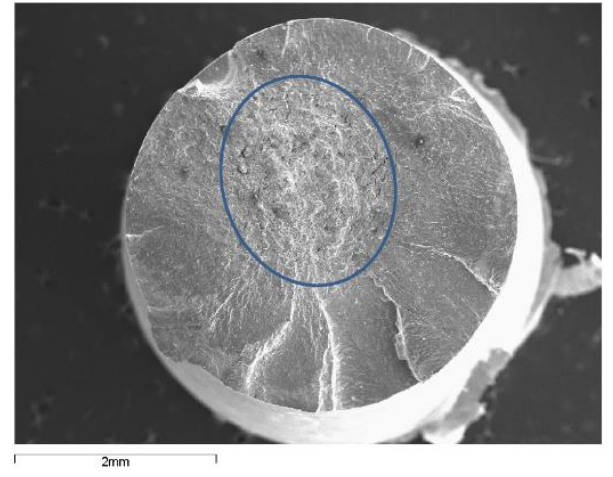

(a)

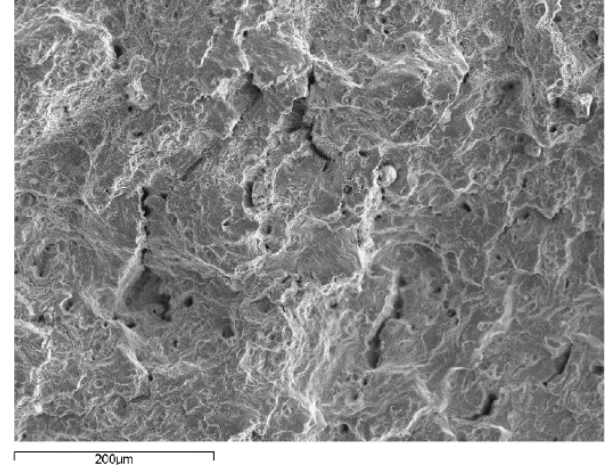

(b)

Figure 9. Fracture surface of chromium-quenched and tempered steel (41CrS4-EC) subjected to the rotational bending fatigue test with a stress of $586 \mathrm{MPa}$. (Complete fracture surface (a) and detail (b)).

\section{Conclusions}

First, it was shown that the 30MnB5-B2 steel, despite having higher yield strength and tensile strength values than the reference steel 30MnB5-B1, does not improve its response to fatigue. For the reference steel, 30MnB5-B1, in the tests carried out with loads below $500 \mathrm{MPa}$, failure was not reached before $10^{6}$ cycles, while for the modified steel, failure still occurred for tests with loads below 400. MPa. This response is understood taking into account the inverse relationship that exists between the yield strength in the conventional mechanical behavior of the material and the fracture toughness associated with the brittle fracture process. In Fracture Mechanics, it is known that the maximum crack length in a material is inversely proportional to its yield strength; therefore, when the yield strength is raised, the material is structurally weakened, favoring the unstable propagation of cracks.

Microalloyed steel exhibits lower fatigue strength than the reference quench and tempered steel, even at lower test loads. This trend is confirmed in particular for life cycles greater than $10^{6}$ cycles, given that the fatigue limit of microalloyed steel is $30 \%$ of that of reference quenched and tempered steel.

Chromium-alloyed quench and tempered steel (41CrS4-EC) does present a resistance to fatigue superior to the reference and, in general, to all the others evaluated, especially at a low number of cycles. It is not observed, for the range of $10^{3}-10^{6}$ cycles tested, that in this case the fatigue limit of this steel is reached, which was the case with the reference steel and the microalloyed.

The results obtained for B1 and MV steels seem to indicate that the fatigue limit has a greater relationship with the phenomena of plastic deformation, dislocation displacement, 
and therefore with the yield strength than with the tensile strength. Future research will propose to evaluate whether this result can be extended to the other two steels considered.

Author Contributions: Data curation, J.J.G.-D.; Formal analysis, A.I.G.-D.; Investigation, M.Á.G.L. and M.T.-P.; Methodology, J.J.G.-D., M.Á.G.-L. and M.T.-P.; Supervision, A.I.G.-D. and M.T.-P.; Validation, A.I.G.-D. and M.T.-P.; Writing-original draft, A.I.G.-D. and M.T.-P.; Writing-review \& editing, A.I.G.-D., J.J.G.-D., M.Á.G.-L. and M.T.-P. All authors have read and agreed to the published version of the manuscript.

Funding: This research received no external funding.

Institutional Review Board Statement: Not applicable.

Informed Consent Statement: Not applicable.

Data Availability Statement: Not applicable.

Acknowledgments: The authors would like to acknowledge the supply of material by the company CIE Galfor (member of the CIE Automotive group) located in Ourense, Spain.

Conflicts of Interest: The authors declare no conflict of interest.

\section{References}

1. Túry, G. Contribución de la industria automotriz a la economía doméstica desde el punto de vista centro-periferia = Contribution of the Automotive Industry to the Domestic Economy, from a Center-Periphery Point of View. TLA-MELAUA Rev. Ciencias Soc. 2020, 14, 316-340. [CrossRef]

2. Rezaeinejad, I. Automotive Industry and Its Place in the Economy: Case Study Iran Auto Industry. Asian J. Econ. Financ. Manag. 2021, 5, 23-32.

3. Jovičević-Klug, P.; Podgornik, B. Review on the effect of deep cryogenic treatment of metallic materials in automotive applications. Metals 2020, 10, 434. [CrossRef]

4. Han, C. Research on the Development and Application of Lightweight Automotive Materials. J. Phys. Conf. Ser. 2020, 1676, 012085. [CrossRef]

5. Vukelic, G.; Brnic, J. Predicted fracture behavior of shaft steels with improved corrosion resistance. Metals 2016, 6, 40. [CrossRef]

6. Sahoo, G.; Singh, K.K.; Kumar, V. Quenched and tempered high strength steel: A review. J. Met. Mater. Miner. 2020, 30, 19-29. [CrossRef]

7. Kapadia, B.M. Prediction of the Boron Hardenability. Effect in Steel-A Comprehensive Review. In Hardenability Concepts with Applications to Steel; Doane, D.V., Kirkaldy, J.S., Eds.; AIME-TMS: Warrendale, PA, USA, 1978; pp. 448-482.

8. Yamanaka, K.; Ohmori, Y. Effect of Boron on Transformation of Low-carbon Low-alloy Steels. Trans. Iron Steel Inst. Jpn. 1977, 17, 92-101. [CrossRef]

9. Werner, D.H. Boron and Boron Containing Steels; Verlag Stahleisen mbH: Düsseldorf, Germany, 1995; ISBN 3514005400.

10. Titova, T.I.; Shulgan, N.A.; Malykhina, I.Y. Effect of boron microalloying on the structure and hardenability of building steel. Met. Sci. Heat Treat. 2007, 49, 39-44. [CrossRef]

11. Mejía, I.; Bedolla-Jacuinde, A.; Maldonado, C.; Cabrera, J.M. Hot ductility behavior of a low carbon advanced high strength steel (AHSS) microalloyed with boron. Mater. Sci. Eng. A 2011, 528, 4468-4474. [CrossRef]

12. Jiménez, J.A.; Acosta, P.; Frommeyer, G.; Ruano, O.A. Microestructura y propiedades mecánicas de dos aceros para herramientas con ultra alto contenido de boro. Rev. Metal. 1998, 34, 300-304. [CrossRef]

13. Siebert, C.A.; Doane, D.V.; Breen, D.H. The Hardenability of Steels: Concepts, Metallurgical Influences, and Industrial Applications; American Society for Metals: Materials Park, OH, USA, 1977.

14. Çevik, B.; Şahin, Ö.; Gülenç, B. Flux cored arc welding on 30MnB5 steels used in agricultural mechanisation: Microstructure evolutions and mechanical properties. Sadhana-Acad. Proc. Eng. Sci. 2021, 46, 155. [CrossRef]

15. Güler, H.; Ertan, R.; Özcan, R. Effect of heat treatment on the microstructure and mechanical properties of 30MnB5 boron steel. Mater. Tehnol. 2014, 48, 971-976.

16. Mu, Y.H.; Wang, B.Y.; Zhou, J.; Huang, X.; Li, J. ling Influences of hot stamping parameters on mechanical properties and microstructure of 30MnB5 and 22MnB5 quenched in flat die. J. Cent. South Univ. 2018, 25, 736-746. [CrossRef]

17. Ivanayskiy, E.; Ishkov, A.; Ivanayskiy, A.; Ochakovskii, I. Controlled atmosphere GMAW welding of transportation vehicles and production machines parts made from 30MnB5 steel. MATEC Web Conf. 2018, 216. [CrossRef]

18. Singh, S.S.; Sharma, R. Characterization and evaluation of various materials for automobile components. IJMPERD 2017, 7, 161-174. [CrossRef]

19. Alsaran, A.; Karakan, M.; Çelik, A. The investigation of mechanical properties of ion-nitrided AISI 5140 low-alloy steel. Mater. Charact. 2002, 48, 323-327. [CrossRef]

20. Vorel, I.; Vančura, F.; Pileček, V.; Jirková, H.; Mašek, B. Material-technological modelling of C45 steel die forgings. Procedia Eng. 2015, 100, 714-721. [CrossRef] 
21. Ebrahimi, A.; Moshksar, M.M. Evaluation of machinability in turning of microalloyed and quenched-tempered steels: Tool wear, statistical analysis, chip morphology. J. Mater. Process. Technol. 2009, 209, 910-921. [CrossRef]

22. Bhattacharya, D. Microalloyed Steels for the Automotive Industry. Tecnologia em Metalurgia, Materiais e Mineração 2014, 11, 371-383. [CrossRef]

23. Brnic, J.; Turkalj, G.; Canadija, M.; Niu, J. Experimental determination and prediction of the mechanical properties of steel 1.7225. Mater. Sci. Eng. A 2014, 600,47-52. [CrossRef]

24. Maia, B.I.D.; Futami, A.H.; Oliveira, M.A. De Vanadium alloy steel DIN 30Mnvs6 applied in cold forging process. ISIJ Int. 2018, 58, 2318-2322. [CrossRef]

25. Krajnc, L.; Mrvar, P.; Medved, J. Thermodynamic characterization of multiphase non-metallic inclusions in re-sulphurised steel grades. Mater. Tehnol. 2014, 48, 923-929.

26. Baker, T.N. Microalloyed steels. Ironmak. Steelmak. 2016, 43, 264-307. [CrossRef]

27. ISO 1143:2021; Metallic Materials_Rotating Bar Bending Fatigue Testing; ISO: Geneva, Switzerland, 2021.

28. UNE-EN ISO 683-2:2019; Heat-Treatable Steels, Alloy Steels and Free-Cutting Steels-Part 2: Alloy Steels for Quenching and Tempering; ISO: Geneva, Switzerland, 2019.

29. Queiros, G.W.; Carabias, I.; Sanchez, L.G.; de Salazar, J.M.G.; Criado, A.J. Contribution to The Knowledge of The Action of Boron in the Dual Structure of a Steel 30MnB5 by Means of X-ray Diffraction. J. Mater. Sci. Eng. 2019, 8, 8-11. [CrossRef]

30. UNE-EN 10267:1998; Ferritic-Pearlitic Steels for Precipitation Hardening from Hot-Working Temperatures; ISO: Geneva, Switzerland, 1998.

31. Mašek, B.; Aišman, D.; Jirková, H. Effect of the initial microstructure on the properties of low-alloyed steel upon mini-thixoforming. Mater. Tehnol. 2014, 48, 719-723.

32. Ibrahim, K.; Vorel, I.; Jeníček, Š.; Káňa, J.; Rubešová, K.; Opatová, K.; Kotěšovec, V. A study ofmaterial-technologicalmodelling for choosing the ideal cooling rate for designing production of closed die forgings using $30 \mathrm{MNVS6}$ steel. Ann. DAAAM Proc. Int. $D A A A M$ Symp. 2016, 27, 551-555. [CrossRef]

33. Lesz, S.; Kalinowska-Ozgowicz, E.; Gołombek, K.; Kleczka, M. Structure and properties of surface layers of selected constructional steels after sulfonitriding. Arch. Mater. Sci. Eng. 2010, 42, 21-28.

34. Aliakbari, K. Failure analysis of four-cylinder diesel engine crankshaft. J. Brazilian Soc. Mech. Sci. Eng. 2019, 41, 30. [CrossRef]

35. Knez, M.; Glode, S.; Ruika, M.; Kramberger, J. A rotating bending approach for determination of low-cycle fatigue parameters. Int. J. Fatigue 2010, 32, 1724-1730. [CrossRef]

36. Martinez-Cazares, G.; Mercado-Solis, R.; Bedolla-Gil, Y.; Lozano, D. Continuous estimation of the crack growth rate during rotating-bending fatigue testing. Metals 2019, 9, 275. [CrossRef]

37. Baragetti, S.; Božić; Arcieri, E.V. Stress and fracture surface analysis of uncoated and coated 7075-T6 specimens under the rotating bending fatigue loading. Eng. Fail. Anal. 2020, 112, 104512. [CrossRef]

38. Behrens, B.A.; Bouguecha, A.; Raedt, H.W.; Hadifi, M.S.T. Numerical investigations on the fatigue failure of forging tools due to thermo-mechanical cyclic loading. Int. J. Mater. Form. 2010, 3, 339-342. [CrossRef]

39. Dowling, N.E.; Kampe, S.L.; Kral, M.V. Mechanical Behavior of Materials: Engineering Methods for Deformation, Fracture, and Fatigue; Pearson: Harlow, UK, 2020; ISBN 9781292279374.

40. Avilés, R. Análisis de fatiga en máquinas; Thomson: Madrid, Spain, 2005; ISBN 8497323440.

41. Suresh, S. Fatigue of Materials; Cambridge University Press: Cambridge, UK, 1998 ; p. 679.

42. Grubbs, F.E. Sample Criteria for Testing Outlying Observations. Ann. Math. Stat. 1950, 21, 27-58. [CrossRef]

43. Basquin, O.H. The exponential law of endurance tests. Am. Soc. Test. Mater. Proc. 1910, 10, 625-630.

44. Statistical Analysis of Fatigue Data; ASTM International: West Conshohocken, PA, USA, 1981. [CrossRef]

45. Spindel, J.E.; Haibach, E. The method of maximum likelihood applied to the statistical analysis of fatigue data. Int. J. Fatigue 1979, 1,81-88. [CrossRef]

46. Lorén, S.; Lundström, M. Modelling curved S-N curves. Fatigue Fract. Eng. Mater. Struct. 2005, 28, 437-443. [CrossRef]

47. Myung, I.J. Tutorial on maximum likelihood estimation. J. Math. Psychol. 2003, 47, 90-100. [CrossRef]

48. Engler-Pinto, C., Jr.; Lasecki, J.V.; Sr, R.J.; Allison, J.E. Statistical approaches applied to very high cycle fatigue. In Proceedings of the Fourth International Conference on Very High Cycle Fatigue (VHCF-4), Ann Arbor, MI, USA, 19-22 August 2007; Allison, J.E., Jones, J.W., Larsen, J.M., Ritchie, R.O., Eds.; TMS (The Minerals, Metals \& Materials Society): Warrendale, PA, USA, 2007; pp. 369-376.

49. Martín Meizoso, A.; Martínez-Esnaola, J.M.; Gil Sevillano, J. Cálculo del Límite de Fatiga mediante el Método de Máxima Verosimilitud. An. Mecánica Fract. 2009, 2, 406-410. 